This manuscript is contextually identical with the following published paper:

Mojzes, A., Ónodi, G., Lhotsky, B., Kalapos, T., Csontos, P., Kröel-Dulay, Gy. (2018) Within-generation and transgenerational plasticity in growth and regeneration of a subordinate annual grass in a rainfall experiment. Oecologia 188(4): 1059-1068.

DOI: $10.1007 / \mathrm{s} 00442-018-4264-6$

The original published pdf available in this website:

https://link.springer.com/article/10.1007/s00442-018-4264-6

Title page

Within-generation and transgenerational plasticity in growth and regeneration of a subordinate annual grass in a rainfall experiment

Andrea Mojzes $^{1 *}$, Gábor Ónodi ${ }^{1,2}$, Barbara Lhotsky ${ }^{1}$, Tibor Kalapos ${ }^{3}$, Péter Csontos ${ }^{4}$, György Kröel-Dulay ${ }^{1,2}$

${ }^{1}$ MTA Centre for Ecological Research, Institute of Ecology and Botany, Alkotmány u. 2-4, H-2163 Vácrátót, Hungary

${ }^{2}$ MTA Centre for Ecological Research, GINOP Sustainable Ecosystems Group, Klebelsberg Kuno u. 3, H-8237 Tihany, Hungary

${ }^{3}$ Eötvös Loránd University, Institute of Biology, Department of Plant Systematics, Ecology and Theoretical Biology, Pázmány P. stny 1/C, H-1117 Budapest, Hungary

${ }^{4}$ MTA Centre for Agricultural Research, Institute for Soil Sciences and Agricultural Chemistry, Herman O. út 15, H-1022 Budapest, Hungary

* Corresponding author; E-mail: mojzesandrea@gmail.com; Tel.: +36 28 360122; +36 28 360147; Fax: +36 28360110 


\section{Within-generation and transgenerational plasticity in growth and regeneration of a subordinate annual grass in a rainfall experiment}

\section{Abstract}

3 Precipitation changes may induce shifts in plant species or life form dominance in

4 ecosystems, making some previously subordinate species abundant. The plasticity of certain 5 plant functional traits of these expanding subordinate species may be one possible mechanism 6 behind their success.

7 In this study, we tested if the subordinate winter annual grass Secale sylvestre shows plasticity

8 in growth and reproduction in response to altered environment associated with field-scale

9 rainfall manipulations (severe drought, moderate drought, watering) in a semiarid grassland, 10 and whether the maternal environment influences offspring germination or growth in a 11 subsequent pot experiment.

12 Compared to control plots, S. sylvestre plants grew $38 \%$ taller, and produced $32 \%$ more seeds 13 in severe drought plots, while plants in watered plots were $17 \%$ shorter, and had $22 \%$ less 14 seeds. Seed mass was greatest in severe drought plots. Plants growing in drought plots had 15 offspring with enhanced juvenile shoot growth compared to the progeny whose mother plants grew in watered plots. These responses are most likely explained by the decreased cover of 17 previously dominant perennial grasses in severe drought plots, which resulted in wetter soil 18 compared to control and watered plots during the peak growth of S. sylvestre.

19 We conclude that the plasticity of this subordinate annual species in response to changing environment may help to gain dominance with recurring droughts that suppress perennial

21 grasses. Our results highlight that exploring both within-generation and transgenerational 
22 plasticity of subordinate species may lead to a better prediction of changes in plant species 23 dominance under climate change.

24

\section{Keywords}

26 climate change, maternal environment, plant trait, population interaction, Secale sylvestre 27 


\section{Introduction}

In arid and semiarid grasslands, water availability is a strong determinant of plant diversity, primary production, and community stability (Sala et al. 1988; Bai et al. 2004; Suttle et al. 2007; Seddon et al. 2016). In these ecosystems, altered precipitation regimes can often result in shifts in functional group abundances, species reordering or even replacement of species within a community (Suttle et al. 2007; Smith et al. 2009; Scott et al. 2010; Dudney et al. 2017). In such cases, altered conditions may favour coexisting subordinate or transient species at the expense of previous dominants (Mariotte et al. 2013; Yang et al. 2016). The identification of mechanisms at the level of functional group or individual species underlying these marked vegetation changes can be important to better understand and predict the impacts of climate change.

Plant functional traits of subordinate species have received relatively little attention compared to dominant species, despite the evidence that subordinates can also play a substantial role in maintaining ecosystem functions under stress (Walker et al. 1999; Mariotte et al. 2013; Mariotte 2014). Furthermore, the fact that subordinate species are often impacted indirectly by altered climatic conditions via changes in competitive interactions with the dominant species (Kardol et al. 2010; Mariotte et al. 2013, but see Levine et al. 2010) can make their response more difficult to forecast. This highlights the need to improve our understanding of how traits of subordinate species respond to altered climate change drivers, such as precipitation.

Phenotypic plasticity is one of the key mechanisms - besides shifts in species distribution and evolutionary adaptation - that can allow plant populations to adjust to climate change (Nicotra et al. 2010; Franks et al. 2014; Parmesan and Hanley 2015). Phenotypic plasticity is defined as the ability of a single genotype to express different phenotypes under different environmental conditions (Franks et al. 2014). Plasticity of various plant traits, such as plant 
height, leaf size, specific leaf area, and seed size and number is considered to be important in species responses to climate change (Nicotra et al. 2010). However, the plasticity of certain regeneration traits, such as seed germination and seedling growth are highly unknown, despite the critical role of early life history stages in plant population persistence (Walck et al. 2011; Parmesan and Hanley 2015).

Plastic response of an individual to environmental conditions can be expressed not only in its own phenotype (within-generation phenotypic plasticity). Maternal environmental effect (or transgenerational phenotypic plasticity) refers to the phenomenon when the ecological environment experienced by the mother plant influences the offspring's phenotype independently of the genetic inheritance of causative alleles (Roach and Wulff 1987; Herman and Sultan 2011). It can be mediated by multiple, often interacting mechanisms, for instance changes in seed provisioning (i.e. the allocation of nutritive reserves to the developing seed), seed hormone content, or epigenetic marks (such as DNA methylation; Herman and Sultan 2011). The potential importance of transgenerational plasticity in plant species' responses to global environmental changes is highlighted by an increasing number of studies (e.g. Hovenden et al. 2008; Pías et al. 2010; Schuler and Orrock 2012; Fenesi et al. 2014; Walter et al. 2016). If the progeny environment is reliably predictable from the maternal environment e.g. for species with short-distance seed dispersal (Galloway and Etterson 2007) - the mother can adjust the phenotype of her offspring to enhance its performance under conditions that it is likely to encounter (Agrawal et al. 1999; Sultan et al. 2009; Herman and Sultan 2011; Fenesi et al. 2014). However, when increased stochasticity in temperature and/or precipitation associated with climate change decrease the reliability of environmental cues, transgenerational effects could reduce offspring performance (Schuler and Orrock 2012). Climate change experiments in natural vegetation have shown that rainfall manipulations in the maternal environment could influence various traits of offspring including seed 
germination and viability, seedling growth or leaf $\mathrm{C}: \mathrm{N}$ ratio. However, most of these studies focused on dominant species (Breen and Richards 2008; Pías et al. 2010; Tielbörger and Petrů 2010; Chamorro et al. 2016; Walter et al. 2016), and little research addressed the responses of other coexisting species (e.g. Li et al. 2011).

In semiarid regions, ecosystems on sandy soils can be particularly sensitive to precipitation changes, partly due to the low water-holding capacity of the soil (Yang et al. 2010; Gao et al. 2015; Huang et al. 2017). This is also the case in the open perennial sand grassland component of the Pannonian sand forest-steppe in Hungary (Kovács-Láng et al. 2000). For example, extreme droughts in 2000 and 2003 resulted in a marked drop in the cover of the dominant perennial grasses, with a concomitant increase in the abundance of previously subdominant or subordinate annuals in these grasslands in the Danube-Tisza Interfluve, Central Hungary (Kovács-Láng et al. 2006). With a higher probability of drought in summer projected for the country (Bartholy et al. 2014), such annual-dominated patches may persist. The aims of this study were to assess 1) how the altered environment associated with fieldscale experimental rainfall manipulations in a perennial sand grassland affect the growth, seed production, and seed mass of the characteristic subordinate winter annual grass Secale sylvestre, and 2) whether changes in the maternal environment caused by rainfall treatments influence the seed germination and offspring growth of this species in a subsequent pot experiment. We hypothesized that $\left(\mathrm{H}_{1}\right)$ plants growing in the experimental plots (mother plants) show plasticity in the studied traits in response to the different environment resulting from rainfall treatments; $\left(\mathrm{H}_{2}\right)$ the effect of maternal environment manifests in the offspring generation.

\section{Materials and methods}


104 The study site is located in the Danube-Tisza Interfluve, near the village Fülöpháza $105\left(46^{\circ} 52^{\prime} \mathrm{N}, 19^{\circ} 25^{\prime} \mathrm{E}\right)$ in the Kiskunság National Park. The climate is moderately warm 106 semiarid temperate with continental and sub-Mediterranean influences. Annual mean 107 temperature is $10.4{ }^{\circ} \mathrm{C}$, and yearly average precipitation is 500-550 mm (1961-1990; Kovács108 Láng et al. 2000). Midsummer drought is typical in July and August, and it is amplified by the 109 coarse-textured calcareous sand soil.

110 The species selected for our study, Secale sylvestre Host is one of the most frequent winter 111 annual grasses in open sand grasslands of the area. It is a characteristic subordinate 112 component of perennial grasslands, but may become abundant on bare soils as a colonizer 113 during secondary succession after disturbance (Kovács-Láng et al. 2000; Molnár 2003).

114 In 2015, we set up an experiment in an open sand grassland characterised by the 115 dominance of two perennial bunchgrasses, Festuca vaginata Waldst. and Kit. ex Willd. and 116 Stipa borysthenica Klokov ex Prokudin. Experimental units were $3 \mathrm{~m} \times 3 \mathrm{~m}$ plots with a 50 $117 \mathrm{~cm}$ buffer strip along each side inside the boundaries of each plot, thus the effective sampling 118 area was $2 \mathrm{~m} \times 2 \mathrm{~m}$. Plots were laid out in a completely randomized block design with three 119 treatments and a control (ambient rainfall), in six replicates (6 blocks, each block containing 120 one plot of each treatment). Treatments were as follows: severe drought from late June to late 121 August (ca. two months), moderate drought from late July to late August (ca. one month), and 122 watering as one event of ca. $25 \mathrm{~mm}$ per month from late May to late August (i.e. $100 \mathrm{~mm}$ per 123 year, ca. $20 \%$ increase over the long-term annual mean; for exact dates see Table 1). Thus, at 124 the beginning of this study on S. sylvestre (April 2016), treatment plots had received one year 125 of rainfall manipulations (in 2015). Treatments were repeated also in 2016 with a similar 126 timing, but $S$. sylvestre plants studied received only the first watering treatment in late May 127 before completing their life cycle in early June. 
Drought treatments were conducted by excluding rain from the plots using permanent, transparent plastic foils. Watering treatment was applied by using spraying heads at $1 \mathrm{~m}$ height, in a $1 \mathrm{~m} \times 1 \mathrm{~m}$ grid. Side curtains were used during both treatments to avoid water

131 addition to the plots neighbouring watered plots or prevent rain coming from the side to 132 drought plots.

133 Air temperature at $20 \mathrm{~cm}$ height and volumetric soil water content (SWC, \%) at 0-30 cm 134 depth (i.e. averaged over the entire soil profile up to $30 \mathrm{~cm}$ ) were recorded in each plot by 135 installed temperature and moisture sensors (Sensirion SHT75 and Campbell CS616, 136 respectively) connected to a data logger. Precipitation was measured with rain gauges (Davis 137 DS7852) at $30 \mathrm{~cm}$.

139 Background conditions for the studied S. sylvestre plants: precipitation, soil water content and plant abundance

141 Severe and moderate drought treatments excluded $62 \%$ and $49 \%$ of ambient rainfall, 142 respectively, while watered plots received 50\% more rainfall than control plots between 1 143 May and 31 August 2015 (Table 1). During this 4-month period on average, rain exclusions 144 decreased soil water content from $4.0 \%$ (control) to $3.2 \%$ and $3.4 \%$ in severe and moderate 145 drought plots, respectively, whereas watering treatment increased average SWC to $4.3 \%$. 146 Severe drought treatment in summer 2015 decreased the cover of $F$. vaginata and $S$. 147 borysthenica by ca. $80 \%$ by April 2016 compared to April 2015, while in watered plots the 148 cover of these perennial grasses increased by 20\% (Table 1). As a result, in April 2016, the 149 abundance of the two dominant perennial grasses in severe drought plots was $83 \%$ lower than 150 in control plots, and $87 \%$ lower than in watered plots. On the contrary, the cover of $S$. 151 sylvestre increased almost fivefold in severe drought plots from April 2015 to April 2016, 
152 which led to eightfold and fourfold higher abundance of this grass in these plots than in

153 watered and control plots, respectively, in April 2016.

\section{Field sampling and data collection}

In April 2016, 10 individuals were selected and marked for repeated measurements within the 4- $\mathrm{m}^{2}$ sampling area of each plot. We measured the maximum (vegetative) shoot height

158 (stretched length of the shoot; accuracy $0.5 \mathrm{~cm}$ ) according to the protocol of Cornelissen et al.

159 (2003). The length of ear without arista was measured in early June, in the ripening phase, when caryopses (referred to as seeds hereafter) had reached their final size, but were not yet loosening (Lancashire et al. 1991). For the few individuals that developed tiller(s), the longest shoot and ear were chosen. Seed number per ear was estimated by using a linear regression equation $\left(\mathrm{r}^{2}=0.98, P<0.0001\right)$ between the length and seed number of ears determined on an additional 30 individuals outside, but close to the experimental plots at the same date. Fullyripened seeds from 15-20 randomly selected individuals per plot were collected on 9 June 2016, when most of the S. sylvestre plants had completed their life cycle. Seeds were stored in paper bags at room temperature (ca. $28{ }^{\circ} \mathrm{C}$ in summer and $15{ }^{\circ} \mathrm{C}$ in winter) until used for the germination experiment. Fifty "apparently viable" seeds per plot (i.e. that appeared to be intact and resisted gentle pressure; Roberts 1981) were weighed individually (accuracy 0.1 $\mathrm{mg}$ ) to determine mean single seed mass.

\section{Germination and growth experiment}

173 To examine the effects of maternal environment on offspring germination and growth, a 174 common garden pot experiment was set up in Fót $\left(47^{\circ} 37^{\prime} \mathrm{N}, 19^{\circ} 10^{\prime} \mathrm{E}\right)$, ca. $83 \mathrm{~km}$ from the 175 field site, on 16 March 2017. In this experiment, 4 half-litre pots were used to represent one 176 experimental field plot. Thus, 96 pots in total (4 treatments, 6 blocks) filled with nutrient-poor 
sandy soil were placed onto the bench of an outdoor, open-air growth facility. Pots were

178 exposed to natural weather conditions except for excluding precipitation by a transparent 179 plexiglass roof. From each plot of the field experiment, 36 seeds were sown in four pots $(9$ 180 seeds per pot). Final percentage of germination (i.e. coleoptile emerged $\geq 2 \mathrm{~mm}$ above the soil 181 surface) was determined after 35 days. Seedlings were thinned to the largest $(\geq 5 \mathrm{~cm})$ one per 182 pot, and were grown under well-watered conditions (as the major growth period of this grass 183 (April-May) is usually not water-limited). Pots were rotated weekly on the bench to minimize 184 the micro-environmental differences associated with pot position. Until the end of July, when shoot biomass was harvested, only 11 individuals entered the reproductive phase, and 85 plants remained vegetative (most likely due to the lack of exposure to chilling required for

187 flowering; Chouard 1960). Shoot height was measured at two life stages: for 3-week-old 188 plants (juveniles, which had two fully-expanded leaves), and for 4-month-old plants (referred to as adults). In addition, total leaf number and the length of fully-expanded leaves were determined at juvenile stage. Juvenile shoot size was calculated by multiplying the total 191 number of leaves by the length of the longest fully-expanded leaf. This index is frequently 192 used as a non-destructive estimate for biomass, particularly of juvenile plants (e.g. Van

193 Groenendael and Slim 1988; Vergeer and Kunin 2013). It showed strong correlation with 194 juvenile shoot biomass also for $S$. sylvestre (Pearson's $r=0.90, P<0.0001$ ), measured on an 195 additional 30 three-week-old plants in a separate experiment. Green (live) biomass was 196 harvested from 4-month-old adult plants (referred to as adult biomass), oven-dried at $60{ }^{\circ} \mathrm{C}$ 197 for $48 \mathrm{~h}$ and weighed. Reproductive adults and those that died during the experiment (4 198 plants) were excluded from data collection at adult stage. Thus, in the growth experiment, 1-4 199 individuals (pots) corresponded to a single treatment plot of the field experiment. 
For each plant response variable, statistical analyses were done on mean values per plot as the experimental unit $(n=6)$. General Linear Mixed Models with treatment as a fixed effect and block as a random factor were conducted for maximum shoot height, seed number per ear, and mean single seed mass of maternal generation. Data met the assumptions of normality of residuals and homoscedasticity (Quinn and Keough 2002). For post-hoc comparison of means Tukey's HSD tests were used. In order to assess the effect of shoot height on seed number and seed mass after controlling for the effect of treatments, shoot height was also included in the model as a continuous predictor variable, and the partial correlation coefficients $(\mathrm{R})$ were calculated.

For monthly average SWC during the growth and reproduction of the studied plants, twoway repeated measures ANOVA was used with treatment as a fixed effect and month as the repeated-measures effect. Subsequently, Tukey's HSD tests were applied between treatments within each month separately. For each analysis, the TIBCO Statistica software (TIBCO Software Inc. 2017) was used, and differences were considered significant at $P<0.05$.

\section{Maternal generation}

219 During the peak growth period of the maternal generation of S. sylvestre, soil water content 220 was higher in severe drought plots than in both watered and control plots in May 2016 (severe 221 drought and watered plots differed also in April with marginal significance: $P=0.091$; Fig. $2221)$.

Rainfall manipulations had a significant effect on each plant response variable studied in $S$. sylvestre growing in the plots of the field experiment (Table 2). Plants growing in severe drought plots had both higher maximum vegetative shoot height and higher seed number per

226 ear than those growing in control and watered plots (Fig. 2a, b). Consistently, individuals 
growing in moderate drought plots also showed higher values than those in watered plots.

228 Mean single seed mass was greater in severe drought plots than in control and the other treatment plots (Fig. 2c). Difference between the highest and the lowest treatment means

230 (severe drought and watering, respectively), expressed as percentage of the lowest mean 231 ([(Max-Min)/Min] $\times 100, \%)$, was 3.7-times higher in seed number $(68.9 \%)$ than in seed mass 232 (18.6\%). However, when controlling for the effect of treatments, both of these components of 233 reproductive success showed a strong positive partial correlation with shoot height $(\mathrm{R}=0.89$, $P<0.0001$ for seed number; $\mathrm{R}=0.74, P=0.0012$ for seed mass).

Offspring generation

Seeds produced in control and rainfall manipulated plots did not differ in final germination percentage $(67-80 \%)$; only a marginally significant difference $(P=0.086)$ was found between watering and moderate drought treatments; Table 2, Fig. 3a). However, maternal environment had significant effects on the three-week-old offspring (Table 2, Fig. 3b, c, d). Both juvenile shoot size and the length of the first fully-expanded leaf were higher for the offspring whose

242 mother plants grew in severe or moderate drought plots than for the progeny whose mothers 243 developed in watered plots (Fig. 3b, c). Similar differences were found in juvenile shoot 244 height, though severe drought and watering treatments differed with only marginal 245 significance $(P=0.058$; Fig. 3d). At the time of harvest, neither shoot height nor shoot 246 biomass of the adult progeny varied significantly with the environment of their mothers 247 (Table 2, Fig. 3e, f).

\section{Discussion}


Shoot growth and seed production of the studied S. sylvestre plants provided evidence in 253 favour of $\mathrm{H}_{1}$, which was that $S$. sylvestre growing in the experimental plots exhibited 254 phenotypic plasticity in the studied traits in response to the different environment caused by rainfall manipulations. The positive relationships of both seed mass and number with shoot height indicate that on average at plot level, plants experiencing better resource availability can allocate more assimilate to both vegetative growth and reproduction. Lower variation in seed mass than in number is consistent with the previous consideration that seed size is often the least plastic component of reproductive yield within a species (Harper et al. 1970). Nevertheless, S. sylvestre has a limited seed dispersal capacity, and most seeds fall beneath the mother plant. For such species, density-dependent mortality can be high, e.g. due to intense competition between progeny seedlings, thus larger maternal plants may benefit from producing larger seeds (Venable 1992). The seed number and mass values obtained across treatments in our study were within or close to the wide range reported for these traits in several populations of this species within the Kiskunság region (i.e. 5.3-7.9 $\mathrm{g}$ for thousand seed mass, and 12 and 26 as a minimum and maximum number of grains per ear, respectively;

267 Vörösváry et al. 2000).

In several other water manipulation experiments in arid and semiarid ecosystems, reduction in the amount of rainfall usually limited plant growth and/or seed production, 270 whereas increased water supply had an opposite effect (e.g. Poulin et al. 2007; Breen and 271 Richards 2008; Gao et al. 2015; Volis et al. 2015). In contrast, S. sylvestre in our study, 272 showed enhanced growth and reproductive performance in the experimental plots exposed to 273 2-month drought in the previous year, particularly compared with the individuals growing in 274 plots that received supplemental watering. The most probable explanation for these apparently 275 contradictory results is that $S$. sylvestre was not impacted directly by dry conditions (either in 2762015 or 2016), because this grass usually completes its life cycle in early June, i.e. before the 
start of severe drought treatment in late June (Table 1). This phenological rhythm is typical for winter annual species in sand grasslands (Kárpáti and Kárpáti 1954). However, this subordinate species might have benefited indirectly from rain exclusion, as severe drought treatment in 2015 negatively affected the abundance (and thus the competitive effect) of the two dominant perennial grasses, which did not recover by April 2016 (Table 1). This likely resulted in better resource (particularly water) availability for $S$. sylvestre during its peak growth period in spring 2016. In contrast, the moderate increase in the cover of dominant perennials in response to watering during summer 2015 (Table 1), might have enhanced the suppression of the coexisting annual S. sylvestre in spring 2016. This interpretation is supported by the higher soil water content in severe drought plots compared to watered plots in April and particularly in May 2016 (Fig. 1), most likely due to the lower transpirational water loss of the decreased perennial grass cover.

Our results also suggest that with recurring severe droughts, the higher abundance of $S$. sylvestre in severe drought plots in April 2016 after a single 2-month drought of the previous summer (Table 1) may be further augmented by the enhanced growth and reproductive capacity of this annual grass due to the negative response of the concurrent dominant perennial grasses to drought. Similar to our results, in a California grassland, experimentally extended spring rainfall imposed limited direct effects on winter annual grasses due to their early phenology, but in the subsequent year, these grasses benefited indirectly from the decomposition of the initially expanding N-fixing forbs (Suttle et al. 2007). Our results are also in line with those of Violle et al. (2006), who reported that the experimental removal of standing biomass of the dominant perennial grass (with the retention of litter) enhanced the total final and the seed biomass per plant of two early successional annual species in an oldfield. 
In our study, S. sylvestre in watered plots was directly exposed to watering in May both in 2015 and 2016, during flowering. However, the competitive effect of the dominant perennial grasses might have overridden the potential direct positive impact of supplemental water on the annual S. sylvestre. Similarly, in another water manipulation experiment in a mountain steppe, Liancourt et al. (2013) demonstrated that the negative effects of competition with neighbouring plants (including dominant species) could offset the direct benefit of added water on the above-ground biomass of a characteristic species. However, the net effect of supplemental rainfall may depend on how strongly precipitation change alters competition, and also on the sensitivity of inferior species to the altered competitor abundance (Levine et al. 2010).

\section{Plasticity of offspring generation}

In agreement with $\mathrm{H}_{2}$, which was that differences in the maternal environment caused by

314 rainfall manipulations affected the offspring generation of $S$. sylvestre, we found plasticity in 315 the growth of progeny at the juvenile stage. In contrast, seed germination percentage and the 316 adult growth of offspring were not influenced by the environmental conditions of their mother 317 plants. When seed dormancy is imposed by biochemical constraints, drought during seed 318 development usually decreases dormancy and increases germinability (Fenner 1991), which 319 has also been demonstrated in some recent rainfall manipulation experiments with annual 320 species (Karimmojeni et al. 2014; Gao et al. 2015). Nevertheless, some other studies reported 321 similar or higher germination percentage in response to better water conditions in the maternal 322 environment (Poulin et al. 2007; Breen and Richards 2008; Pías et al. 2010; Li et al. 2011). In the juvenile phase, the size of both the first leaf and the whole shoot was greater for the 324 progeny whose mothers grew in drought plots compared with the offspring whose mothers 325 developed in watered plots. This indicates that mother plants experiencing less competitive 
and thus more favourable (moisture) environment (i.e. in severe and moderate drought plots, where the cover of dominant perennial grasses was low; Table 1) facilitated the early growth of their offspring. Larger plant size in the early phase of the life cycle might provide a great advantage for survival, as mortality rate of young plants is often high (Leishman et al. 2000), and can be size-dependent within a species, especially in resource-limited conditions, such as 331 under water stress (Cook 1980; Parker 1982). Such a positive maternal effect can allow 332 offspring to avoid the initial time lag that is required for the development of the offspring's own plasticity to its actual environment (Agrawal et al. 1999; Herman and Sultan 2011).

334 Numerous prior studies reported that better water availability for the studied species in the 335 maternal environment had positive transgenerational effects on offspring growth in early 336 seedling or juvenile stage, i.e. in the phase that can be critical for establishment (Breen and 337 Richards 2008; Pías et al. 2010; Li et al. 2011; Walter et al. 2016). Larger seedlings usually 338 germinate from larger seeds, and greater seed mass often reflects a higher amount of seed 339 reserves (Leishman et al. 2000). In our experiment, greater mass was detected only for seeds 340 produced in severe drought plots, thus other potential mechanisms than seed provisioning 341 (reviewed by Herman and Sultan 2011) should (also) account for the differences in juvenile 342 growth observed between the progeny whose mother plants grew in severe or moderate 343 drought plots and in watered plots.

344 We found no difference in shoot height and biomass of four-month-old progeny according 345 to the environment of their mothers. These results are consistent with previous studies 346 reporting that the beneficial maternal effects diminished or disappeared in a later stage of 347 offspring's life cycle (Pías et al. 2010; Walter et al. 2016), but contrast with the other studies 348 where positive transgenerational effect was detected in the final fitness of adult progeny or 349 both in an earlier and adult stages (Roach and Wulff 1987; Fenesi et al. 2014). The 350 persistence of positive maternal influence may depend on its underlying mechanism (Herman 
and Sultan 2011), and also on the environmental conditions experienced by the offspring. For

352 example, the improved seedling vigour of Austrian winter field peas established from large 353 seeds could increase the seed yield compared to the yield of peas planted from small seeds 354 under adverse conditions, but not in environment more favourable for pea growth at 355 Grangeville, Idaho (Murray et al. 1984). Thus, the fact that in our experiment, the progeny of 356 S. sylvestre were grown under well-watered conditions might provide one possible 357 explanation why the benefit of enhanced growth of juveniles did not appear in the adult stage. 358 Nevertheless, to our best knowledge, our study provides the first experimental evidence that 359 altered rainfall amounts, this key element of climate change, can trigger transgenerational 360 effects on offspring growth of a subordinate species indirectly via changes in the competitive 361 interactions with the dominant species.

\section{Conclusions}

364 Our field experiment showed that a subordinate species in perennial sand grasslands, $S$. 365 sylvestre exhibited phenotypic plasticity in shoot growth and seed production when growing 366 in different environments caused by a single year of rainfall manipulations. This plasticity is 367 most likely a response to the altered population interactions in the growth environment 368 resulting from the previous-year precipitation changes, which led to enhanced performance of 369 this species with decreasing amount of rainfall. Moreover, maternal environmental effect 370 found in the early growth of offspring might amplify the immediate response that can be 371 achieved by within-generation plasticity alone (Sultan et al. 2009; Herman and Sultan 2011). 372 Based on these results, we expect that summer drying projected for Hungary in the future 373 (Bartholy et al. 2014) will favour the growth and reproduction of S. sylvestre. This better 374 performance may contribute to the increase in abundance of this annual grass, and thus to the 375 shift from perennial grasses to annuals in sand grasslands of the study region. Our study 
highlights that both within-generation and transgenerational plasticity of subordinate species

377 should be taken into account to better understand and predict shifts in plant species or 378 functional group abundances under climate change.

\section{Acknowledgements}

381 This work is a part of the projects no. 120844 and no. 112576, which has been implemented 382 with the support provided by the National Research, Development and Innovation Fund 383 (NRDI Fund) of Hungary, financed under the PD_16 (A.M.) and K (G.K-D.) funding scheme, 384 respectively. This study was also part of the project Sustainable Use of Ecosystem Services 385 (GINOP-2.3.2-15-2016-00019) funded by the NRDI Office (G.K-D. and G.Ó.). This research 386 was also supported by the János Bolyai Research Scholarship of the Hungarian Academy of 387 Sciences (G.K-D.). We are grateful to the Kiskunság National Park for the support to our field work. We thank Péter Ódor for his advice on statistical analyses. We also thank the two anonymous reviewers for their helpful comments on an earlier version of the manuscript.

\section{Author contribution statement}

392 G.K-D. designed and established the rainfall manipulation experiment. A.M. and G.K-D. 393 conceived the concept of the research. A.M. conducted fieldwork with the help of B.L. in 394 developing the methodology. G.Ó. collected and processed the micrometeorological and 395 vegetation cover data. A.M., T.K. and P.C. designed, and A.M. performed the pot experiment. 396 A.M. analysed the data, and wrote the manuscript with major inputs from all co-authors.

\section{Compliance with ethical standards}

399 Conflict of interest The authors declare that they have no conflict of interest. 
400 Ethical approval This article does not contain any studies with human participants or animals

401 performed by any of the authors.

402

\section{References}

404 Agrawal AA, Laforsch C, Tollrian R (1999) Transgenerational induction of defences in 405 animals and plants. Nature 401:60-63 doi:10.1038/43425

406 Bai Y, Han X, Wu J, Chen Z, Li L (2004) Ecosystem stability and compensatory effects in the 407 Inner Mongolia grassland. Nature 431:181-184 doi:10.1038/nature02850

408 Bartholy J, Pongrácz R, Pieczka I (2014) How the climate will change in this century? Hung 409 Geogr Bull 63:55-67 doi:10.15201/hungeobull.63.1.5

410 Breen AN, Richards JH (2008) Irrigation and fertilization effects on seed number, size, 411 germination and seedling growth: implications for desert shrub establishment. Oecologia 157:13-19 doi:10.1007/s00442-008-1049-3

413 Chamorro D, Parra A, Moreno JM (2016) Reproductive output, seed anatomy and 414 germination under water stress in the seeder Cistus ladanifer subjected to experimental 415 drought. Environ Exp Bot 123:59-67 doi:10.1016/j.envexpbot.2015.11.002

416 Chouard P (1960) Vernalization and its relations to dormancy. Ann Rev Plant Physiol 11:191417238 doi:10.1146/annurev.pp.11.060160.001203

418 Cook RE (1980) Germination and size-dependent mortality in Viola blanda. Oecologia 419 47:115-117 doi:10.1007/BF00541785

420 Cornelissen JHC, Lavorel S, Garnier E, Díaz S, Buchman N, Gurvich DE, Reich PB, ter 421 Steege H, Morgan HD, van der Heijden MGA, Pausas JG, Poorter H (2003) A handbook of 422 protocols for standardised and easy measurement of plant functional traits worldwide. Aust $423 \quad$ J Bot 51:335-380 doi:10.1071/BT02124 
424 Dudney J, Hallett LM, Larios L, Farrer EC, Spotswood EN, Stein C, Suding KN (2017)

425 Lagging behind: have we overlooked previous-year rainfall effects in annual grasslands? J

426 Ecol 105:484-495 doi:10.1111/1365-2745.12671

427 Fenesi A, Dyer AR, Geréd J, Sándor D, Ruprecht E (2014) Can transgenerational plasticity 428 contribute to the invasion success of annual plant species? Oecologia 176:95-106 429 doi:10.1007/s00442-014-2994-7

430 Fenner M (1991) The effects of the parent environment on seed germinability. Seed Sci Res 1:75-84 doi:10.1017/S0960258500000696

432 Franks SJ, Weber JJ, Aitken SN (2014) Evolutionary and plastic responses to climate change 433 in terrestrial plant populations. Evolut Appl 7:123-139 doi:10.1111/eva.12112

434 Galloway LF, Etterson JR (2007) Transgenerational plasticity is adaptive in the wild. Science $435 \quad 318: 1134-1136$ doi:10.1126/science. 1148766

436 Gao R, Yang X, Liu G, Huang Z, Walck JL (2015) Effects of rainfall pattern on the growth 437 and fecundity of a dominant dune annual in a semi-arid ecosystem. Plant Soil 389:335-347 438 doi:10.1007/s11104-014-2366-4

439 Harper JL, Lovell PH, Moore KG (1970) The shapes and sizes of seeds. Ann Rev Ecol Syst $440 \quad$ 1:327-356 doi:10.1146/annurev.es.01.110170.001551

441 Herman JJ, Sultan SE (2011) Adaptive transgenerational plasticity in plants: case studies, 442 mechanisms, and implications for natural populations. Front Plant Sci 2:1-10 443 doi:10.3389/fpls.2011.00102

444 Hovenden MJ, Wills KE, Chaplin RE, Vander Schoor JK, Williams AL, Osanai YUI, Newton 445 PC (2008) Warming and elevated $\mathrm{CO}_{2}$ affect the relationship between seed mass, 446 germinability and seedling growth in Austrodanthonia caespitosa, a dominant Australian 447 grass. Glob Change Biol 14:1633-1641 doi:10.1111/j.1365-2486.2008.01597.x 
448 Huang Y, Yu X, Li, E, Chen H, Li L, Wu X, Li X (2017) A process-based water balance

449 model for semi-arid ecosystems: A case study of psammophytic ecosystems in Mu Us 450 Sandland, Inner Mongolia, China. Ecol Model 353:77-85 451 doi:10.1016/j.ecolmodel.2017.01.005

452 Kardol P, Campany CE, Souza L, Norby RJ, Weltzin JF, Classen AT (2010) Climate change 453 effects on plant biomass alter dominance patterns and community evenness in an 454 experimental old-field ecosystem. Glob Change Biol 16:2676-2687 doi:10.1111/j.1365$455 \quad 2486.2010 .02162 . x$

456 Karimmojeni H, Bazrafshan AH, Majidi MM, Torabian S, Rashidi B (2014) Effect of 457 maternal nitrogen and drought stress on seed dormancy and germinability of Amaranthus $458 \quad$ retroflexus. Plant Species Biol 29:e1-e8 doi:10.1111/1442-1984.12022

459 Kárpáti I, Kárpáti V (1954) The aspects of the calciphilous turf (Festucetum vaginatae 460 danubiale) in the environs of Vácrátót in 1952. Acta Bot Acad Sci Hung 1:129-157

461 Kovács-Láng E, Kröel-Dulay Gy, Kertész M, Fekete G, Bartha S, Mika J, Dobi-Wantuch I, 462 Rédei T, Rajkai K, Hahn I (2000) Changes in the composition of sand grasslands along a 463 climatic gradient in Hungary and implications for climate change. Phytocoenologia 30:385$464 \quad 407$ doi:10.1127/phyto/30/2000/385

465 Kovács-Láng E, Kröel-Dulay Gy, Rédei T, Lhotsky B, Garadnai J (2006) The effect of 466 climate change on forest-steppe ecosystems in the Carpathian Basin, In: Láng I, Faragó T, 467 Iványi Zs (eds) International Conference on Climate Change: Impacts and Responses in 468 Central and Eastern European Countries. 5-8 November 2005, Pécs, pp 294-300

469 Lancashire PD, Bleiholder H, van Den Boom T, Langelüddeke P, Stauss R, Weber E, 470 Witzenberger A. (1991) A uniform decimal code for growth stages of crops and weeds. Ann 471 Appl Biol 119:561-601 doi:10.1111/j.1744-7348.1991.tb04895.x 
472 Leishman MR, Wright IJ, Moles AT, Westoby M (2000) The evolutionary ecology of seed

473 size. In: Fenner M (ed) Seeds: The Ecology of Regeneration in Plant Communities, $2^{\text {nd }}$ edn., 474 CAB International, Wallingford, pp 31-57

475 Levine JM, McEachern AK, Cowan C (2010) Do competitors modulate rare plant response to 476 precipitation change? Ecology 91:130-140 doi:10.1890/08-2039.1

477 Li Y, Yang H, Xia J, Zhang W, Wan S, Li L (2011) Effects of increased nitrogen deposition 478 and precipitation on seed and seedling production of Potentilla tanacetifolia in a temperate 479 steppe ecosystem. PLoS ONE 6:e28601 doi:10.1371/journal.pone.0028601

480 Liancourt P, Spence LA, Song DS, Lkhagva A, Sharkhuu A, Boldgiv B, Helliker BR, 481 Petraitis PS, Casper BB (2013) Plant response to climate change varies with topography, 482 interactions with neighbors, and ecotype. Ecology 94:444-453 doi:10.1890/12-0780.1

483 Mariotte P (2014) Do subordinate species punch above their weight? Evidence from above484 and below-ground. New Phytol 203:16-21 doi:10.1111/nph.12789

485 Mariotte P, Vandenberghe C, Kardol P, Hagedorn F, Buttler A (2013) Subordinate plant 486 species enhance community resistance against drought in semi-natural grasslands. J Ecol $487 \quad$ 101:763-773 doi:10.1111/1365-2745.12064

488 Molnár Zs (ed) (2003) A Kiskunság száraz homoki növényzete. (Dry sand vegetation of the 489 Kiskunság). TermészetBÚVÁR Alapítvány Kiadó, Budapest (in Hungarian with English $490 \quad$ translation)

491 Murray GA, Swensen JB, Auld DL (1984) Influence of seed size and planting date on the 492 performance of Austrian winter field peas. Agron J 76:595-598 493 doi:10.2134/agronj1984.00021962007600040021x

494 Nicotra AB, Atkin OK, Bonser SP, Davidson AM, Finnegan EJ, Mathesius U, Poot P, 495 Purugganan MD, Richards CL, Valladares F, van Kleunen M (2010) Plant phenotypic 
496 plasticity in a changing climate. Trends Plant Sci 15:684-692

497 doi:10.1016/j.tplants.2010.09.008

498 Parker MA (1982) Association with mature plants protects seedlings from predation in an arid

499 grassland shrub, Gutierrezia microcephala. Oecologia 53:276-280

500 doi:10.1007/BF00545677

501 Parmesan C, Hanley ME (2015) Plants and climate change: complexities and surprises. Ann

502 Bot 116:849-864 doi:10.1093/aob/mcv169

503 Pías B, Matesanz S, Herrero A, Gimeno TE, Escudero A, Valladares F (2010)

504 Transgenerational effects of three global change drivers on an endemic Mediterranean plant.

$505 \quad$ Oikos 119:1435-1444 doi:10.1111/j.1600-0706.2010.18232.x

506 Poulin J, Sakai AK, Weller SG, Nguyen T (2007) Phenotypic plasticity, precipitation, and 507 invasiveness in the fire-promoting grass Pennisetum setaceum (Poaceae). Am J Bot 94:533$508 \quad 541$ doi:10.3732/ajb.94.4.533

509 Quinn GP, Keough MJ (2002) Experimental Design and Data Analysis for Biologists. 510 Cambridge University Press, New York

511 Roach DA, Wulff RD (1987) Maternal effects in plants. Ann Rev Ecol Syst 18:209-235 512 doi:10.1146/annurev.es.18.110187.001233

513 Roberts HA (1981) Seed banks in soils. Adv Appl Biol 6:1-55.

514 Sala OE, Parton WJ, Joyce LA, Lauenroth WK (1988) Primary production of the central 515 grassland region of the United States. Ecology 69:40-45 doi:10.2307/1943158

516 Scott RL, Hamerlynck EP, Jenerette GD, Moran M., Barron-Gafford GA (2010) Carbon 517 dioxide exchange in a semidesert grassland through drought-induced vegetation change. $\mathbf{J}$ $518 \quad$ Geophys Res 115:G03026 doi:10.1029/2010JG001348 
519 Schuler MS, Orrock JL (2012) The maladaptive significance of maternal effects for plants in anthropogenically modified environments. Evolut Ecol 26:475-481 doi:10.1007/s10682011-9499-1

Seddon AW, Macias-Fauria M, Long PR, Benz D, Willis KJ (2016) Sensitivity of global terrestrial ecosystems to climate variability. Nature 531:229-232 doi:10.1038/nature16986

Smith MD, Knapp AK, Collins SL (2009) A framework for assessing ecosystem dynamics in response to chronic resource alterations induced by global change. Ecology 90:3279-3289 doi:10.1890/08-1815.1

Sultan SE, Barton K, Wilczek AM (2009) Contrasting patterns of transgenerational plasticity 528 in ecologically distinct congeners. Ecology 90:1831-1839 doi:10.1890/08-1064.1

529 Suttle KB, Thomsen MA, Power ME (2007) Species interactions reverse grassland responses 530 to changing climate. Science 315:640-642 doi:10.1126/science.1136401

531 TIBCO Software Inc. (2017) Statistica (data analysis software system), version 13 (Trial 532 version), http://statistica.io

533 Tielbörger K, Petrů M (2010) An experimental test for effects of the maternal environment on 534 delayed germination. J Ecol 98:1216-1223 doi:10.1111/j.1365-2745.2010.01682.x

535 Van Groenendael JM, Slim P (1988) The contrasting dynamics of two populations of 536 Plantago lanceolata classified by age and size. J Ecol 76:585-599 doi:10.2307/2260614

537 Venable DL (1992) Size-number trade-offs and the variation of seed size with plant resource 538 status. Am Nat 140:287-304 doi:10.1086/285413

539 Vergeer P, Kunin WE (2013) Adaptation at range margins: common garden trials and the 540 performance of Arabidopsis lyrata across its northwestern European range. New Phytol $541 \quad$ 197:989-1001 doi:10.1111/nph.12060 
542 Violle C, Richarte J, Navas ML (2006) Effects of litter and standing biomass on growth and 543 reproduction of two annual species in a Mediterranean old-field. J Ecol 94:196-205 544 doi:10.1111/j.1365-2745.2005.01061.x

545 Volis S, Ormanbekova D, Yermekbayev K (2015) Role of phenotypic plasticity and 546 population differentiation in adaptation to novel environmental conditions. Ecol Evol $547 \quad$ 5:3818-3829 doi:10.1002/ece3.1607

548 Vörösváry G, Már I, Holly L, Kissimon J (2000) Analysis of genetic polymorphisms in 549 jointed goatgrass (Aegilops cylindrica) and annual wild rye (Secale sylvestre) populations 550 from Hungary. Port Acta Biol 19:137-147

551 Walck JL, Hidayati SN, Dixon KW, Thompson K, Poschlod P (2011) Climate change and 552 plant regeneration from seed. Glob Change Biol 17:2145-2161 doi:10.1111/j.1365$553 \quad 2486.2010 .02368 . x$

554 Walker B, Kinzig A, Langridge J (1999) Plant attribute diversity, resilience, and ecosystem 555 function: the nature and significance of dominant and minor species. Ecosystems 2:95-113 556 doi:10.1007/s100219900062

557 Walter J, Harter DE, Beierkuhnlein C, Jentsch A (2016) Transgenerational effects of extreme 558 weather: Perennial plant offspring show modified germination, growth and stoichiometry. $\mathbf{J}$ $559 \quad$ Ecol 104:1032-1040 doi:10.1111/1365-2745.12567

560 Yang HL, Huang ZY, Ye YZ, Zhu XW, Dong M, Weng HB (2010) Effects of soil moisture 561 profile on seedling establishment in the psammophyte Hedysarum laeve in the semiarid 562 Otindag Sandland, China. J Arid Environ 74:350-354 doi:10.1016/j.jaridenv.2009.09.014 563 Yang Z, Jiang L, Su F, Zhang Q, Xia J, Wan S (2016) Nighttime warming enhances drought 564 resistance of plant communities in a temperate steppe. Sci Rep 6:23267 565 doi: $10.1038 / \operatorname{srep} 23267$ 
566 Table 1 Precipitation (total sum) and daily average volumetric soil water content (SWC, \%)

567 between 1 May and 31 August 2015 (i.e. during the period covering each treatment in the year 568 preceding our study) and cover (\%) of the two dominant perennial grasses Festuca vaginata 569 and Stipa borysthenica, and Secale sylvestre in the experimental plots in April (i.e. prior to the 570 current year's treatments). For SWC and cover data, data are means \pm SE $(n=6)$

\begin{tabular}{|c|c|c|c|c|}
\hline & \multicolumn{4}{|c|}{ Treatment } \\
\hline & Control & $\begin{array}{c}\text { Severe } \\
\text { drought }\end{array}$ & $\begin{array}{c}\text { Moderate } \\
\text { drought }\end{array}$ & Watering \\
\hline Treatment period & - & $23.06-25.08$ & $22.07-25.08$ & $\begin{array}{l}18.05,22.06, \\
21.07,25.08\end{array}$ \\
\hline (number of days) & $(-)$ & (63) & (34) & (4 distinct) \\
\hline Precipitation (mm) & 196.0 & 74.2 & 100.6 & 294.5 \\
\hline $\mathrm{SWC}(\%)$ at $0-30 \mathrm{~cm}$ & $4.0 \pm 0.1$ & $3.2 \pm 0.1$ & $3.4 \pm 0.1$ & $4.3 \pm 0.1$ \\
\hline $\begin{array}{l}\text { Cover }(\%) \text { of } F \text {. vaginata } \\
\text { and } S . \text { borysthenica } \\
(2015)\end{array}$ & $10.0 \pm 1.1$ & $9.6 \pm 1.3$ & $9.3 \pm 1.1$ & $12.8 \pm 0.9$ \\
\hline $\begin{array}{l}\text { Cover }(\%) \text { of } F \text {. vaginata } \\
\text { and } S . \text { borysthenica } \\
(2016)\end{array}$ & $12.0 \pm 1.5$ & $2.0 \pm 0.5$ & $7.2 \pm 1.1$ & $15.4 \pm 0.8$ \\
\hline $\begin{array}{l}\text { Cover (\%) of S. sylvestre } \\
(2015)\end{array}$ & $0.58 \pm 0.22$ & $0.96 \pm 0.31$ & $0.76 \pm 0.25$ & $0.22 \pm 0.04$ \\
\hline $\begin{array}{l}\text { Cover (\%) of S. sylvestre } \\
(2016)\end{array}$ & $1.1 \pm 0.3$ & $4.5 \pm 1.0$ & $2.7 \pm 0.9$ & $0.55 \pm 0.14$ \\
\hline
\end{tabular}


571 Table 2 Results of General Linear Mixed Models for traits of maternal and offspring

572 generations of Secale sylvestre. Mother plants grew in the field experiment in 2016 and

573 offspring in a common garden pot experiment. $P$-values of $<0.05$ are considered significant.

574 Subscripts on F-values are degrees of freedom of the numerator (MS Predictor) and

575 denominator (MS Error), respectively

\begin{tabular}{lcc}
\hline $\begin{array}{l}\text { Plant response variable } \\
\text { (predictor) }\end{array}$ & $\mathrm{F}_{3 ; 15}$ & $P$ \\
\hline $\begin{array}{l}\text { Maternal generation } \\
\text { Shoot height }(\mathrm{cm})\end{array}$ & 16.34 & $<0.0001$ \\
Seed number per ear & 11.96 & 0.00029 \\
Mean seed mass (mg) & 8.69 & 0.0014 \\
Offspring generation & & \\
Final germination \% & 2.81 & 0.075 \\
Juvenile shoot size $(\mathrm{cm})$ & 5.25 & 0.011 \\
First leaf length $(\mathrm{cm})$ & 4.34 & 0.022 \\
Juvenile shoot height $(\mathrm{cm})$ & 5.03 & 0.013 \\
Adult shoot height $(\mathrm{cm})$ & 0.16 & 0.92 \\
Adult biomass $(\mathrm{mg})$ & 1.31 & 0.31 \\
\hline
\end{tabular}




\section{Figure legends}

577 Fig. 1 Effects of rainfall manipulations on volumetric soil water content (\%) at 0-30 cm depth 578 in the plots of the field experiment during the period of growth and reproduction of the 579 studied Secale sylvestre plants (maternal generation). Values are treatment means $\pm \mathrm{SE}(\mathrm{n}=6)$ 580 in each month. Treatments are watering (W), control (C), moderate drought (M), severe 581 drought $(\mathrm{S})$. Different letters above the bars denote significant $(P<0.05)$ differences, while 582 N.S. indicates the lack of significant differences between treatments within each month 583 separately. Results of Tukey's HSD tests following two-way repeated measures ANOVA are 584 shown

Fig. 2 Effects of previous-year (2015) rainfall manipulations on a) maximum vegetative shoot height $(\mathrm{cm})$, b) seed number per ear and c) mean single seed mass (mg) of Secale sylvestre growing in the plots of the field experiment in 2016 (maternal generation). Values are treatment means \pm SE $(n=6)$. Treatment symbols are defined in the legend of Fig. 1. Different letters above the bars indicate significant $(P<0.05)$ differences between treatments. Results of Tukey's HSD tests following General Linear Mixed Models are shown

Fig. 3 Effects of differences in the maternal environment resulting from rainfall manipulations (which were applied in 2015) on Secale sylvestre (offspring generation), whose mothers grew in the plots of the field experiment in 2016. Offspring were grown in a subsequent common garden pot experiment. Plant response variables include a) final germination percentage (\%), b) juvenile shoot size calculated by multiplying the total number of leaves by the length of the longest fully-expanded leaf $(\mathrm{cm}), \mathbf{c})$ length of the first fully-expanded leaf $(\mathrm{cm}), \mathbf{d})$ juvenile shoot height $(\mathrm{cm})$, e) adult shoot height $(\mathrm{cm})$, and $\mathbf{f})$ adult live biomass $(\mathrm{mg})$. Values are treatment means \pm SE $(n=6)$. The treatments of the field experiment are abbreviated as in 
601 Fig. 1. The statistical tests applied, and the indication of significant $(P<0.05)$ differences

602 between treatments are the same as described in Fig. 2 
Fig. 1

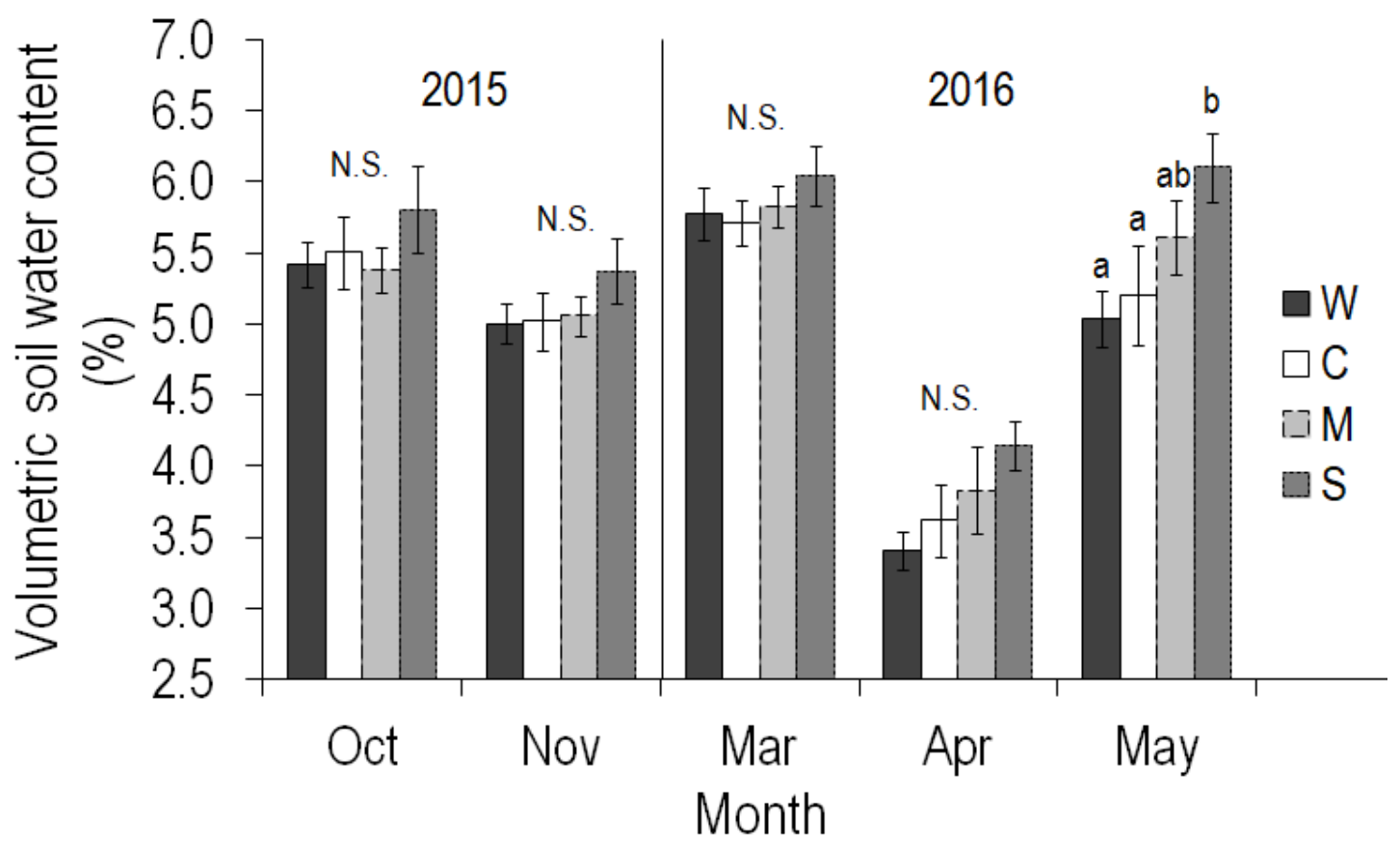


Fig. 2
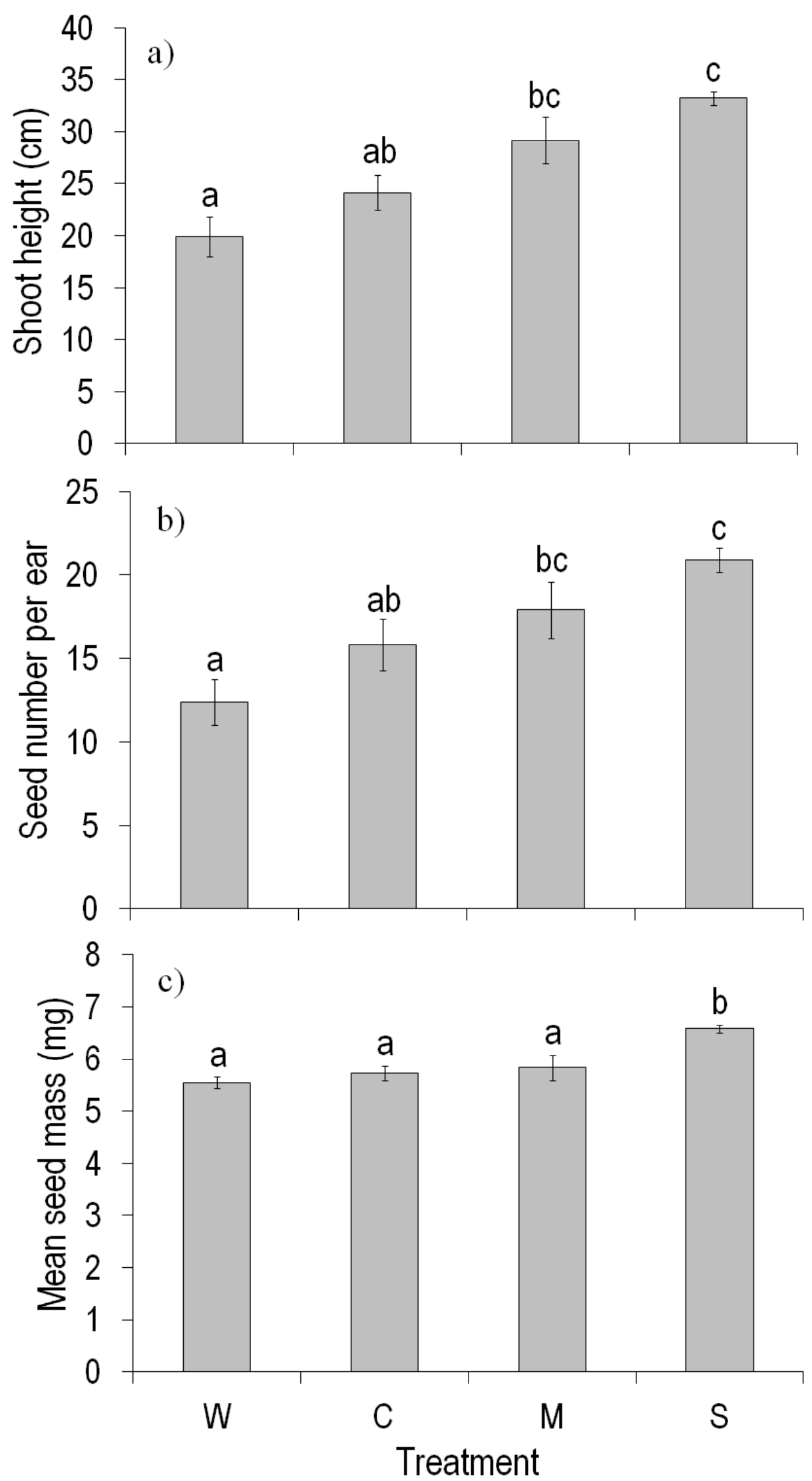
Fig. 3
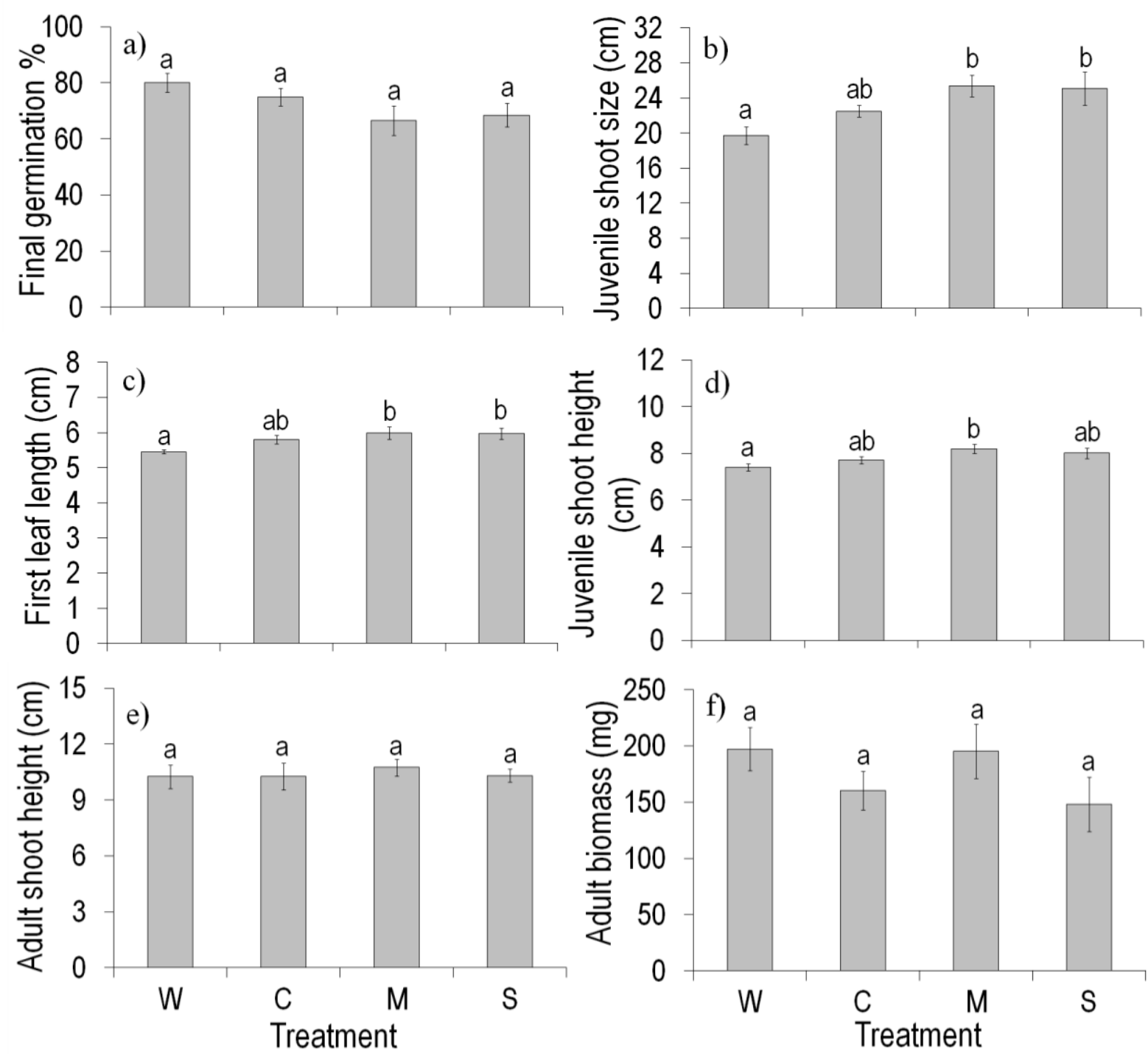